\title{
Pelatihan Manajemen Mitigasi Bencana Erupsi Gunung Api Kelud Di SDN Penataran 1 Kecamatan Nglegok Kabupaten Blitar
}

\author{
Ika Meviana ${ }^{1)}$ \\ Nelya Eka Susanti ${ }^{1)}$ \\ 1) Universitas Kanjuruhan Malang \\ nelyaeka@unikama.ac.id
}

\begin{abstract}
ABSTRAK: Erupsi Gunung Api Kelud terakhir terjadi pada tanggal 13-14 Februari 2014. Erupsi yang bersifat eksplosif menyebabkan lontaran material vulkanik setinggi 17 kilometer dan memuntahan lava pijar yang disertai semburan abu vulkanik serta kerikil yang menyebabkan hujan abu vulkanik. Desa Penataran, Kecamatan Nglegok merupakan salah satu daerah di Kabupaten Blitar yang rawan terkena dampak erupsi Gunung api Kelud. Menurut laporan Disaster Manageman Center Dompet Dhuafa tanggal 14 Februari 2014 di Kecamatan Nglegok tercatat ada 50 anak yang mengalami gangguan psikologi karena dampak erupsi Gunung Api Kelud. Bencana erupsi gunung api tidak bisa dicegah, karena itu perlu dilakukan persiapan untuk menghadapi konsekuensi tersebut dengan melakukan manajemen mitigasi bencana melalui pendidikan untuk anak usia dini.Program Abdimas ini menekankan pada pelatihan manajemen mitigasi bencana, khususnya bencana erupsi gunung api kelud. Materi pelatihan disusun atas dasar analisis kebutuhan peserta yang dilaksanakan melalui pelatihan. Dengan demikian materi pelatihan betulbetul sesuai kebutuhan dan agar bisa berjalan efektif dan efisien.Hasil evalusi siswa tentang pemahaman manajemen mitigasi bencana erupsi Gunung Api Kelud di SDN Penataran 01 bagus, dibuktikan dengan nilai rata-rata siswa yang mengikuti pelatihan 82,25. Berdasarkan hasil pengabdian disarankan perlu adanya penambahan waktu untuk melakukan pelatihan mitigasi bencana erupsi gunung api agar memperoleh hasil yang maksimal.
\end{abstract}

Kata kunci: Pelatihan, Mitigasi Bencana, Erupsi, Gunung Api

\begin{abstract}
The last Kelud Volcano eruption occurred on February 13-14, 2014. Explosive eruptions caused volcanic material bursts as high as 17 kilometers and spewed incandescent lava accompanied by bursts of volcanic ash and gravel which caused rain of volcanic ash. Penataran Village, Nglegok District is one of the areas in Blitar District which is prone to being affected by the eruption of the Kelud volcano. According to the Dompet Dhuafa Disaster Management Center report dated February 14, 2014 in Nglegok District, there were 50 children who experienced psychological disorders due to the eruption of the Kelud Volcano. The volcanic eruption disaster cannot be prevented, because it is necessary to prepare to face these consequences by carrying out disaster mitigation management through education for young children. The training material was prepared on the basis of the analysis of the participants' needs which were carried out through the training. Thus the training material is really as needed and in order to run effectively and efficiently. The results of the evaluation of students about understanding the management of the eruption of Mount Kelud eruption in SDN Penataran 01 are good, evidenced by the average value of students who took 82.25 training. Based on the results of the dedication, it is suggested that there is need to increase the time to conduct volcano eruption disaster mitigation training in order to obtain maximum results.
\end{abstract}

Keywords: Training, Disaster Mitigation, Eruption, Volcano

\section{PENDAHULUAN}

Gunung Api Kelud secara administratif terletak di tiga Kabupaten yaitu Kediri, Blitar dan Malang. Letak geografis Gunung Kelud 7056' LS dan 112018' BT. Gunung Api 
Kelud memiliki ketinggian 1.731 meter dari permukaan air laut. Gunung Api Kelud merupakan gunung api strato aktif tipe A bersifat freato magmatik sampai magmatik (Kusumadinata dkk, 1979). Kondisi morfologis Gunung Api Kelud ditandai dengan bentuk kawah seperti tapal kuda, hal ini mencirikan terjadinya erupsi secara berulang dan bersifat ekplosif (Bachri, dkk, 2017).

Erupsi Gunung Api Kelud terakhir terjadi pada tanggal 13-14 Februari 2014. Volume material letusan diperkirakan mencapai 100 -120 juta m3 dengan sebaran material mengarah ke sisi barat dan utara, dimana potensi material lahar lebih dari 50 juta $\mathrm{m} 3$ (BNPB, 2014). Erupsi yang bersifat exsplosif menyebabkan lontaran material vulkanik setinggi 17 kilometer dan memuntahan lava pijar yang disertai semburan abu vulkanik serta kerikil yang menyebabkan hujan abu vulkanik. Gunung api ini memiliki material erupsi piroklastik yang mengalir, lontaran, ledakan lateral, longsoran puing-puing dan lava mengalir memiliki dampak langsung terhadap lingkungan.

Masyarakat Kabupaten Kediri, Kabupaten Blitar dan Kabupaten Malang terkena dampak erupsi yang paling besar terutama kerugian material. Kegiatan masyarakat di kecamatan tersebut juga terhenti. Sekolah-sekolah diliburkan semetara waktu karena tertutup abu vulkanik. Dampak erupsi gugung api biasanya hanya difokuskan pada segi material saja. Dampak psikologis yang ditimbulkan akibat bencana masih terabaikan. Menurut laporan Disaster Manageman Center Dompet Dhuafa tanggal 14 Februari 2014 tercatat 561 anak ditiga kecamatan yaitu Kediri, Blitar dan Malang mengalami ganggunan psikologis akibat erupsi Gunung Api Kelud.

Penelitian Kurniawati (2014) menunjukkan hasil yang sama, bencana erupsi gunung api mengakibatkan adanya trauma pada siswa terutama di daerah rawan bencana. Aktivitas belajar siswa sempat menurun akibat bencana erupsi tersebut. Banyak siswa yang menjadi korban dikarenakan rumah mereka terendam pasir bahkan ada yang hilang. Perasaan trauma dan stress ini membawa dampak siswa tidak optimal dalam belajar di sekolah.

Anak-anak sangat rentan menjadi korban bencana karena kemampuan dan pengetahuannya terkait mitigasi bencana sangat minim, terutama anak-anak yang berada di desa (Putra, dkk., 2014). Kurangnya informasi menjadi salah satu faktor minimnya pengetahuan anak-anak di desa terkait karakteristik dan mitigasi bencana di daerah mereka, sehingga mereka tidak siap untuk menghadapinya. Padahal potensi anak-anak di desa menjadi korban bencana sangat besar.

Pendidikan manajemen mitigasi bencana gunungapi untuk anak usia dini merupakan salah satu alternatif mengurangi jumlah korban dan ganggunan psikologis pada anak-anak (Lestari, dkk, 2012). Pelatihan manajemen bencana yang berlangsung menunjukkan bahwa sebelum bencana datang diperlukan kesiapsiagaan, mitigasi, dan pencegahan. Setelah bencana datang diperlukan penanganan darurat (tangap darurat), rehabilitasi (perbaikan akibat bencana), dan rekonstruksi (pembangunan kembali). 
Desa Penataran, Kecamatan Nglegok merupakan salah satu daerah di Kabupaten Blitar yang rawan terkena dampak erupsi Gunung api Kelud. Menurut laporan Disaster Manageman Center Dompet Dhuafa tanggal 14 Februari 2014 di Kecamatan Nglegok tercatat ada 50 anak-anak yang mengalami gangguan psikologi karena dampak erupsi Gunung Api Kelud. Bencana erupsi Gunung api tidak bias dicegah, karena itu perlu dilakukan persiapan untuk menghadapi konsekuensi tersebut dengan melakukan manajemen mitigasi bencana melalu pendidikan untuk anak usia dini.

Berdasarkan uraian diatas, perlu diadakan pelatihan manajeman mitigasi bencana erupsi Gunung Api Kelud untuk anak usia dini khususnya anak SD. Karena keterbatasan waktu, dana, dan tenaga, pelatihan ini hanya dilakukan di SDN Penataran 1. SDN tersebut berada di Kecamatan Nglegok dan terkena dampak erupsi Gunung Api Kelud. Harapannya setelah diberikan pelatihan ini dapat meningkatkan pengetahuan anak-anak dalam menghadapi risiko bencana gunung api sehingga dapat mengurangi risiko trauma atau strees pada saat terjadi bencana.

Berdasarkan analisis situasi, secara umum permasalahan yang dihadapi adalah; 1) kurangnya informasi tentang karakteristik bencana erupsi Gunung api Kelud; kurangnya pelatihan untuk meningkatkan pemahaman dan kesadaran anak-anak dalam menghadapi bencana erupsi gunung api; 3) banyak anak-anak yang mengalami gangguan psikologi akibat erupsi Gunung Api Kelud. Perlu diadakannnya pelatihan manajemen mitigasi bencana untuk mengurangi risiko. Oleh karena itu sangat perlu mengurangi risiko yang ditimbulkan oleh bencana khususnya anak-anak melalui pelatihan manajeman mitigasi bencana. Sehingga permasalahan utamanya adalah "Bagaimana meningkatkan pemahaman anak-anak dalam mengahadapi risiko bencana erupsi gunung api?’.

\section{METODE PELAKSANAAN}

\section{Kerangka Pemecahan Masalah}

Berdasarkan permasalahan yang diuraikan pada bab 1, maka untuk mengatasi masalah yang dihadapi menggunakan kerangka pemecahan masalah dengan solusi yang ditawarkan seperti tabel dibawah ini:

Tabel 1. Kerangka Pemecahan Masalah

\begin{tabular}{|c|c|c|c|c|}
\hline No & Permasalahan & $\begin{array}{l}\text { Metode } \\
\text { Pendekatan }\end{array}$ & $\begin{array}{ll}\text { Solusi } & \text { yang } \\
\text { Ditawarkan } & \end{array}$ & Partisipasi Mitra \\
\hline 1 & $\begin{array}{l}\text { Kurangnya } \\
\text { informasi tentang } \\
\text { karakteristik } \\
\text { bencana erupsi } \\
\text { Gunung Api Kelud }\end{array}$ & Pendidikan & $\begin{array}{l}\text { Pendidikan denagan } \\
\text { memberikan } \\
\text { informasi } \\
\text { katarteristik } \\
\text { bencana erupsi } \\
\text { Gunung Api Kelud. }\end{array}$ & $\begin{array}{l}\text { Menyediakan } \\
\text { perlengkapan } \\
\text { alat-alat tulis, } \\
\text { laptop dan modul. }\end{array}$ \\
\hline 2 & $\begin{array}{l}\text { Kurangnya } \\
\text { pelatihan untuk } \\
\text { meningkatkan } \\
\text { pemahaman dan }\end{array}$ & $\begin{array}{l}\text { Pelatihan dan } \\
\text { pendampingan }\end{array}$ & $\begin{array}{l}\text { Pelatihan dan } \\
\text { pendampingan } \\
\text { siswa dalam } \\
\text { memahami }\end{array}$ & $\begin{array}{l}\text { Menyediakan } \\
\text { perlengkapan } \\
\text { alat-alat tulis, } \\
\text { laptop dan modul. }\end{array}$ \\
\hline
\end{tabular}




\begin{tabular}{|c|c|c|c|c|}
\hline & $\begin{array}{l}\text { kesadaran anak- } \\
\text { anak dalam } \\
\text { menghadapi } \\
\text { bencana erupsi } \\
\text { gunung api. }\end{array}$ & & $\begin{array}{l}\text { manajeman mitigas } \\
\text { becana erupsi } \\
\text { gunung api. }\end{array}$ & \\
\hline 3 & $\begin{array}{l}\text { Banyak anak-anak } \\
\text { yang mengalami } \\
\text { gangguan psikologi } \\
\text { akibat erupsi } \\
\text { Gunung Api Kelud. }\end{array}$ & $\begin{array}{l}\text { Pelatihan dan } \\
\text { pendampingan }\end{array}$ & $\begin{array}{l}\text { Pelatihan dan } \\
\text { pendampingan } \\
\text { sebelum, saat dan } \\
\text { sesudah terjadi } \\
\text { bencana erupsi } \\
\text { gunungapi }\end{array}$ & $\begin{array}{l}\text { Menyediakan } \\
\text { perlengkapan } \\
\text { alat-alat tulis } \\
\text { laptop dan modul. }\end{array}$ \\
\hline
\end{tabular}

Khalayak sasaran dalam program pengabdian masyarakat ini adalah siswa SDN Penataran 1, Kecamatan Nglegok, Kabupaten Blitar. Sedangkan aplikasi pelaksanaan pengabdi di SDN Penataran 1 melibatkan 2 dosen dan 1 mahasiswa sebagai pendamping dan motivator di lapangan.

\section{Rancangan Evaluasi}

Adapun rencana evaluasi untuk menilai keterlaksanan pengabdian pada tabel 3.2 dibawah ini:

Tabel 2. Rancangan Evaluasi

\begin{tabular}{|c|c|c|c|}
\hline No & Kriteria & Indikator & $\begin{array}{l}\text { Tolok ukur } \\
\text { keberhasilan }\end{array}$ \\
\hline 1 & $\begin{array}{l}\text { Pemahaman tentang bencana } \\
\text { erupsi gunung api }\end{array}$ & $\begin{array}{l}\text { Memahami bencana } \\
\text { erupsi gunung api }\end{array}$ & $\begin{array}{l}\text { Siswa mampu } \\
\text { mengerjakan tes } \\
\text { tentang erupsi gunung } \\
\text { api }\end{array}$ \\
\hline 2 & $\begin{array}{l}\text { Melakukan manajeman mitigasi } \\
\text { bencana erupsi gunung api }\end{array}$ & $\begin{array}{l}\text { Dapat melakukan } \\
\text { manajeman mitigasi } \\
\text { benaca erupsi gunung } \\
\text { api }\end{array}$ & $\begin{array}{l}\text { Siswa mampu } \\
\text { melakukan } \\
\text { manajeman mitigasi } \\
\text { bencana erupsi } \\
\text { gunung api }\end{array}$ \\
\hline
\end{tabular}

\section{Metode Pendekatan}

Rendahnya pengetahuan anak-anak tentang manajeman mitigasi bencana erupsi gunung api disebabkan karena kurangnya pemahaman tentang bencana. Oleh karena itu dalam pelatihan ini dilaksanakan dengan metode sebagai berikut. 1) Praktik dan pelatihan langsung sebelum, saat dan sesudah terjadi erupsi gunung api dan 2) Pendampingan.

Agar pelatihan dapat memberikan kontribusi yang besar pada partisipasi siswa dalam pemahaman mitigasi bencana erupsi gunung api, materi pelatihan meliputi: a) Karakteristik bencana eruspsi Gunung Api Kelud, b) Dampak dan daerah-daerah yang 
rawan terkena erupsi Gunung Api Kelud, 3) Persiapan manajeman bencana sebelum bencana datang diperlukan kesiapsiagaan, mitigasi, dan pencegahan. Setelah bencana datang diperlukan penanganan darurat, rehabilitasi dan rekonstruksi.

\section{HASIL DAN PEMBAHASAN}

\section{Situasi Pelaksanaan}

Kegiatan pengabdian pelatihan manajemen mitigasi bencana erupsi Gunung Api Kelud dilaksanakan di SDN Penataran 1, Kecamatan Nglegok Kabupaten Blitar. Kegiatan pengabdian ini dilaksanakan pada hari Sabtu, 26 Januari 2018 pukul 09.30 sampai 11.15 WIB. Siswa yang mengikuti dalam pelaksanaan pengabdian ini adalah siswa kelas V yang berjumlah 12 orang. Pelaksanaan pengabdian dapat dijabarkan dengan rincian kinerja pada tabel berikut:

Tabel 3. Situasi Pelaksanaan Pelatihan Mitigasi Bencana Erupsi Gunung Api Kelud

\begin{tabular}{|c|c|c|c|}
\hline Hari/ Tanggal & Nama Sekolah & Materi & Situasi Pelaksanaan \\
\hline $\begin{array}{l}\text { Sabtu, } \\
\text { 26 Januari } 2018\end{array}$ & $\begin{array}{l}\text { SDN Penataran } 1 \\
\text { Kecamatan } \\
\text { Nglegok, } \\
\text { Kabupaten Blitar }\end{array}$ & $\begin{array}{l}\text { 1. Pengertian gunung api } \\
\text { 2. Pengertian erupsi gunung } \\
\text { api } \\
\text { 3. Macam-macam bentuk } \\
\text { gunung api } \\
\text { 4. Proses terjadinya erupsi } \\
\text { gunung api } \\
\text { 5. Tingkat status gunung } \\
\text { api dan kawasan rawan } \\
\text { bencana } \\
\text { 6. Bahaya letusan gunung } \\
\text { api } \\
\text { 7. Keuntungan dan } \\
\text { kerugian dari bencana } \\
\text { erupsi gunung api } \\
\text { 8. Strategi Mitigasi dan } \\
\text { Upaya Pengurangan } \\
\text { Risiko } \\
\text { 9. Langkah Mitigasi } \\
\text { Gunung Api } \\
\text { 10. Demonstrasi dan } \\
\text { simulasi peristiwa } \\
\text { kejadian longsor lahan } \\
\text { dan mitigasinya sebelum, } \\
\text { saat dan setelah longsor } \\
\text { lahan. } \\
\text { 11. Tes kemampuan } \\
\text { pemahanan siswa tentang } \\
\text { bencana longsor }\end{array}$ & $\begin{array}{l}\text { Keterbatasan media } \\
\text { pembelajaran di kelas, } \\
\text { dalam hal ini LCD, } \\
\text { menyebabkan } \\
\text { pembelajaran yang } \\
\text { berlangsung jarang } \\
\text { menggunakan media } \\
\text { video. Pada saat } \\
\text { pembelajaran yang } \\
\text { dilakukan pada hari } \\
\text { sabtu, siswa sangat } \\
\text { terlihat antusias } \\
\text { melihat video } \\
\text { pembelajaran tentang } \\
\text { pembentukan gunung } \\
\text { api, erupsi gunung api. } \\
\text { Pembelajaran tentang } \\
\text { mitigasi bencana } \\
\text { erupsi gunung api } \\
\text { dilakukan dengan } \\
\text { metode simulasi. } \\
\text { Metode simulasi ini } \\
\text { baru pertama kali } \\
\text { diterapkan di sekolah } \\
\text { SDN Penataran 1. } \\
\text { Pada awalnya siswa } \\
\text { kebingungan saat } \\
\text { melaksanakan } \\
\text { simulasi mitigasi } \\
\text { bencana erupsi } \\
\text { gunung api. Kegiatan } \\
\text { simulasi mitigasi }\end{array}$ \\
\hline
\end{tabular}


bencana erupsi gunung api dilakukan sebanyak dua kali.

- Di akhir pembelajaran, siswa diberikan tes untuk mengetahui dan mengukur pemahaman siswa tentang materi yang sudah diberikan.

\section{Faktor Pendukung}

Faktor pendukung pelaksanaan pengabdian masyarakat sebagai berikut:

1. Adanya dukungan dari Kepala Sekolah dan Guru Kelas untuk mengadakan pelatihan manajemen mitigasi bencana eruosi gunung api.

2. Adanya kepentingan bersama yang saling menguntungkan, yaitu dari pihak sekolah dapat mengadakan kegiatan pelatihan tentang manajemen mitigasi bencana eruosi gunung api kepada para siswa, sehingga siswa menjadi paham dan tanggap terhadap bencana erupsi Gunung Api Kelud.

3. Kecamatan Nglegok termasuk ke dalam Kawasan Rawan Bencana II, sehingga pelaksanaan pelatihan manajemen mitigasi bencana erupsi gunung api kelud dapat bermanfaat khususnya bagi siswa.

4. Fasilitas ruang kelas dan lapangan yang memadai dan dibantu oleh guru kelas yang kooperatif dalam kegiatan pelatihan manajemen mitigasi bencana erupsi gunung api kelud, sehingga kegiatan pelatihan berjalan dengan lancar.

5. Siswa sangat tertarik dengan kegiatan pelatihan, terbukti dari beberapa siswa yang antusias untuk bertanya setelah melihat video.

6. Siswa antusias dan bersemangat mengikuti pelatihan manajemen mitigasi bencana sehingga suasa menjadi menyenangkan.

\section{Faktor Penghambat}

Faktor penghambat dalam kegiatan ini yaitu; (1) minimnya waktu yang diberikan oleh sekolah karena harus menyesuikan dengan pelajaran yang lain sehingga kegiatan pelatihan manajemen mitigasi bencana erupsi Gunung Api Kelud berjalan cukup singkat dan tim pengabdi hanya menyampakan materi secara singkat dan padat; (2) tidak ada 
fasilitas LCD di sekolah tempat melaksanakan pengabdian sehingga tim pengabdi harus menyediakan LCD sendiri.

\section{Hasil yang diperoleh}

Hasil yang diperoleh dari kegiatan pengabdian di SDN Penataran 1 Kecamatan Nglegok Kabupaten Blitar adalah sebagai berikut:

1. Pembelajaran yang dilakukan dengan media video dan poster sangat interaktif. Hal ini dibuktikan dengan siswa yang antusias saat melihat video tentang erupsi gunung api. Hal tersebut menimbulkan rasa ingin tahu siswa muncul. Sebagian besar siswa aktif bertanya berkaitan dengan materi yang ada pada video yang telah ditayangkan oleh tim pengabdi.

2. Pembelajaran yang dilakukan dengan metode demonstrasi dan simulasi mempermudah siswa untuk memahami materi yang telah disampaikan. Berdasarkan hasil pengamatan saat demontrasi dan simulasi manajemen mitigasi bencana erupsi gunung api, siswa menjadi tanggap terhadap peristiwa bencana erupsi gunung api. Sehingga jika terjadi bencana erupsi gunung api siswa tanggap dapat menyelamatkan diri sendiri serta membantu orang lain.

3. Evaluasi yang diberikan pada akhir pembelajaran bermanfaat untk mengetahui pemaham siswa tentang manajemen mitigasi bencana erupsi gunung api. Hasil evaluasi siswa tentang pemahaman manajemen mitigasi bencana erupsi gunung api di SDN Penataran 1 dengan nilai nilai rata-rata 82,25. Berdasarkan hasil evaluasi terdapat beberapa siswa kesulitan memahami istilah-istilah kebencanaan, seperti Kawasan Rawan Bencana (KRB), mitigasi, lahar hujan, dan lempeng.

\section{Pembahasan}

Kecamatan Nglegok merupakan daerah yang termasuk dalam Kawasan Rawan Bencana (KRB) II. Bencana erupsi gunung api dapat merugikan masyarakat, seperti menimbulkan korban jiwa, kerugian dan kehilangan harta benda, dapat menyebabkan kerusakan lingkungan, serta dapat menimbulkan permasalahan psikologis anak-anak menjadi terganggu akibat trauma. Oleh sebab itu diperlukan pengetahuan, pemahaman, 
dan kesiapsiagaan untuk mendeteksi, mencegah dan mengantisipasi serta meminimalisir kerugian sejak dini tentang bencana erupsi gunung api.

Kegiatan pelatihan manajemen mitigasi bencana erupsi Gunung Api Kelud guna membangun pengetahuan dan pemahaman dalam mendeteksi, mencegah, mengantisipasi bencana secara efektif dapat ditransformasikan di tingkat Sekolah dasar. Karena informasi mengenai keberadaan bencana di lingkungan SD masih minim (Nirwansyah, dkk, 2015). Kondisi tersebut mendorong pembelajaran tentang manajemen mitigasi bencana erupsi gunung api perlu diberikan untuk memberikan pemahaman, pengetahuan dan kesiapsiagaan kepada siswa jika terjadi bencana erupsi gunung api.

Pelatihan manajemen mitigasi bencana erupsi gunung api yang diberikan pada siswa tingkat sekolah dasar merupakan salah satu solusi yang dapat diterapkan di Kecamatan Nglegok. Anak-anak yang tinggal di daerah Kecamatan Nglegok Kabupaten Blitar, dimana daerah ini merupakan Kawasan Rawan Bencana (KRB) II membutuhkan pengetahuan tentang cara penyelamatan diri dari bahaya bencana erupsi gunung api. Oleh karena itu pendidikan tentang siaga bencana erupsi gunung api kelud perlu diterapkan dan dikembangkan pada tingkat sekolah dasar. Hal tersebut dilakukan dalam rangka membangun budaya keselamatan dan ketahanan khususnya untuk anak-anak.

Materi yang sesuai untuk diberikan pada pelatihan manajemen mitigasi bencana erupsi Gunung Api Kelud diantaranya pengertian gunung api dan erupsi gunung api, macam-macam bentuk gunung api, proses terjadinya gunung api, tingkat status gunung api dan kawasan rawan bencana, bahaya letusan unung api, keuntungan dan kerugian dari bencana gunung api, strategi mitigasi dan upaya pengurangan risiko, serta langkah mitigasi bencana erupsi gunung api. Materi berkaitan tentang manajemen mitigasi bencana erupsi gunung api perlu dan penting untuk diberikan kepada siswa tingkat sekolah dasar. Dengna memberikan pengetahuan materi tentang mitigasi bencana siswa dapat mengetahui karakteristik bencana dan daerah yang rawan bencana erupsi gunung api. Hasil yang dicapai dari pelatihan manajemen mitigasi bencana ini adalah pengetahuan, sikap, perilaku dalam penanggulangan bencana serta tindakan yang dapat dilakukan saat menghadapi bencana dan pasca bencana erupsi gunung api.

Metode pembelajaran yang diterapkan pada saat pelatihan manajemen mitigasi bencana adalah demonstrasi dan simulasi. Siswa dikenalkan cara penanggulangan 
bencana erupsi gunung api. Dengan diberikannya pelatihan mitigasi bencana siswa dapat melakukan tindakan terhadap bencana yang terjadi di sekitar lingkungan mereka. Siswa terlihat sangat antusias dalam mengikuti kegiatan demonstrasi. Siswa diberi contoh dengan melakukan demonstrasi kegiatan-kegiatan yang dilakukan sebelum, saat dan sesudah terjadinya bencana erupsi gunung api.

Metode demonstrasi merupakan pembelajaran dengan memperagakan barang, kejadian, dan urutan melakukan suatu kegiatan, baik secara langsung maupun melalui penggunaan media yang relevan dengan materi. Metode demonstrasi dilakukan untuk mengatasi kekurangan alat dan bahan pembelajaran. Fungsi metode demonstrasi adalah memberikan pembuktian bagi suatu konsep dengan cara melakukan, mengamati dan menguji. Metode demonstrasi juga membuat pembelajaran lebih menarik, untuk memperkenalkan cara kerja alat atau memperkenalkan penggunaan alat dan bahan untuk melakukan eksperimen.

Metode demonstrasi dapat membuat perhatian siswa berpusat pada apa yang didemonstrasikan. Jadi, dengan diterapkannnya metode demonstrasi dapat membantu proses sosialisasi sehingga lebih terarah dan meminimalisir siswa untuk berbicara dengan teman atau bermain sendiri. Kegiatan demonstrasi dapat merangsang siswa untuk lebih aktif dalam mengikuti demonstrasi. Karena menurut Slameto (2003), untuk memperoleh banyak kemajuan, maka seseorang harus dilatih dalam berbagai aspek tingkah laku sehingga diperoleh suatu pola tingkah laku yang otomatis. Materi yang disajikan juga mempertimbangkan aspek kognitif, afektif, psikomotrik dan lingkungan sekitar, hal ini untuk membantu siswa memahami materi. Selain itu, adanya kerjasama yang tercipta pada saat pembelajaran antarsiswa dapat membantunya memperoleh hasil belajar yang lebih baik.

Setelah siswa memahami materi yang disampaikan saat demnstrasi, siswa melakukan simulasi mitigasi bencana erupsi gunung api. Kegiatan simulasi merupakan tingkah laku seseorang untuk berlaku seperti orang yang dimaksudkan, agar orang itu dapat mempelajari lebih mendalam tentang bagaimana merasa dan berbuat sesuatu. Kegiatan pelatihan mitigasi bencana erupsi gunung api yang dilakukan dengan metode simulasi dapat menambah pengalaman dan membantu siswa untuk mengingat lebih lama 
serta dapat mengurangi kesalah pahaman karena pengajaran dengan metode simulasi lebih kongkrit.

Pelaksanaan kegiatan pelatihan manajemen mitigasi bencana erupsi gunung api tidak hanya menggunakan metode saja, tetapi juga memanfaatkan media berupa video. Berdasarkan hasil wawancara dengan guru dan siswa, di sekolah belum pernah dilakukan kegiatan pelatihan tentang manajemen mitigasi bencana erupsi gunung api. Informasi berkaitan dengan bencana erupsi gunung api diperoleh dari media koran dan televisi, sehingga sangat minim pemahaman tentang mitigasi bencana erupsi gunung api. Senada dengan penelitian Serjati (2015) bahwa pemahaman dan pengetahuan di sekolah tingkat dasar tentang mitigasi bencana erupsi gunung api masih sangat kurang.

Penggunaan media dalam menyampaikan materi tentang manajemen mitigasi bencana dirasa lebih menarik. Media yang baik harus mampu menyampaikan pesan dan juga memotivasi siswa. Dalam hal ini tim pengabdi memilih media visual, karena cocok dengan materi pelatihan manajemen mitigasi benca erupsi gunung api. Media yang bersifat visual antara lain dapat berbentuk peta, foto, ilustrasi gambar, diagram, poster, atau pun komik (Waluyanto, 2010). Media yang dipakai dalam pemberian pelatihan yaitu gambar, poster dan video. Media pembelajaran yang bersifat visual sangat efektif, karena dapat menyampaiakn informasi secara jelas. Hal ini sejalan dengan penelitian Arifianti (2011) bahawa media yang dapat digunakan didalam materi kebencanaan ini adalah peta, gambar, dan film sebagai ilustrasi terjadinya bencana.

Kegiatan pelatihan manajemen mitigasi bencana erupsi Gunung Api Kelud bertujuan untuk memberikan informasi tentang karakteristik bencana erupsi Gunung api Kelud dan memberikan pelatihan untuk meningkatkan pemahaman dan kesadaran anakanak dalam meghadapi bencana erupsi gunung api Kelud. Untuk mengetahui keberhasilan dalam melakukan pelatihan mitigasi bencana erupsi gunung api Kelud, diadakan tes pemahaman siswa tentang manajemen mitigasi bencana erupsi gunung api. Tes berupa soal pilihan ganda berjumlah sepuluh dan soal esai berjumlah 4 yang diberikan di akhir pelatihan.

Hasil dari evaluasi berkaitan dengan pemahaman manajemen mitigasi bencana erupsi gunung api menunjukkan bahwa nilai rata-rata siswa di SDN Penataran 1 sebesar 82,25 tergolong baik. Hal ini diduga karena risiko terdampak bencana erupsi gunung api 
Kelud di SDN Penataran 1 cukup tinggi mengingat daerah Kecamatan Nglegok masuk dalam Kawasan Rawan Bencana (KRB) II. Selain itu siswa juga pernah melihat kejadian bencana erupsi gunung api yang terjadi pada tahun 2014.

Pemahaman tentang mitigasi kebencanaan sebaiknya diberikan sejak usia dini. Karena anak-anak merupakan korban yang paling banyak ketika terjadi bencana. Hal tersebut bisa terjadi dikarenakan minimnya pemahaman anak-anak tentang manajemen mitigasi bencana. Pengetahuan dan pemahaman yang rendah tentang risiko bencana akan menyebabkan kesiapsiagaan dalam menghadapi bencana juga kurang. Siswa yang terbiasa bersinggungan dengan bencana dianggap mampu membuat keputusan dan berperan aktif ketika bencana terjadi, sehingga mereka mengerti bagaimana cara menyelamatkan diri. Siswa yang memiliki pengatahun akan lebih percaya diri, tidak merasa ketakutan dan stress saat terjadi bencana.

\section{KESIMPULAN DAN SARAN \\ Kesimpulan}

Berdasarkan hasil pelaksanaan kegiatan pengabdian pelatihan manajemen mitigasi bencana erupsi gunung api Kelud di SDN Penataran 1 Kecamatan Nglegok Kabupaten Blitar, dapat disimpulkan:

1. Pelaksanaan pengabdian pelatihan manajemen mitigasi bencana erupsi gunung api Kelud di SDN Penataran 1 Kecamatan Nglegok Kabupaten Blitar berlangsung dengan baik, lancar dan memberikan keuntungan bagi kedua belah pihak.

2. Siswa kelas V SDN Penataran 1 yang mengikuti pelatihan manajemen mitigasi bencana erupsi gunung api Kelud bisa memahami materi pelatihan yang sudah diberikan.

3. Pelaksanaan kegiatan sesuai dengan rencana dan mendapat respon yang sangat positif dari peserta pelatihan manajemen mitigasi bencana erupsi gunung api Kelud.

4. Pelaksanaan pengabdian belum bisa maksimal karena terbatasnya waktu yang diberikan.

\section{Saran}

1. Perlu adanya penambahan waktu untuk melakukan pelatihan manajemen mitigasi bencana erupsi gunung api Kelud untuk menghasilkan hasil yang maksimal.

2. Perlu diberikana pelatihan dengan cara simulasi yang rutin kepada siswa agar pemahaman siswa tentang mitigasi kebencanaan meningkat.

3. Pengabdian yang sudah dilakukan diharapkan dapat dilanjutkan pada tahun-tahun berikutnya di lokasi lain untuk meningkatkan kewaspadaan terjadinya bencana erupsi gunung api. 


\section{DAFTAR PUSTAKA}

Arifianti, Yukn. 2011. Buku mengenal tanah longsor Sebagai media pembelajaran bencana sejak dini. Bulletin Vulkanologi dan Bencana Geologi, Volume 6 Nomor 3,Desember $2011: 24-24$.

Astuti, dan Sudaryono. 2010. Peran Sekolah dalam Pembelajaran Mitigasi Bencana. Jakarta. Jurnal Dialog Penanggulangan Bencana, Volume 1 Nomor 1.

Bachri, dkk,. 2017. Hidup selaras bersama gunung api: Kajian dampak positif dari letusan Gunung api kelud tahun 2014 sebagai Modal pembangunan berkelanjutan. Jurnal Pengelolaan Sumberdaya Wilayah Berkelanjutan. ISBN: 978-602-361-072-3, hal. 147-158.

BNPB. Februari 2014. Info Bencana Gunung Kelud. Hal 1-4. (Online), (https://bnpb.go.id/uploads/migration/pubs/596.pdf.), Diakses 1 Januari 2018.

Disaster Manageman Center Dompet Dhuafa. 14 Februari 2014. Erupsi Gunung Kelud. Hal. 1-6, (Online), (http:// Sitrep-DMC-Dompet-Dhuafa-Respon-Erupsi-GunungKelud-4-Maret 2014.pdf), Diakses 1 Januari 2018.

Kurniawati. 2014. Pengelolaan pembelajaran pendidikan dasar Pasca erupsi merapi. Jurnal Manajemen Pendidikan. Vol. 9, No. 120 2, hal 120-129, (Online), (https://media.neliti.com/.../112702-ID-pengelolaan-pembelajaran-pendidikandasa.pdf), Diakses 1 Januari 2018.

Kusumadinata, K., dkk,.1979.Data Dasar Gunung api Indonesia, Bandung: Direktorat Vulkanologi.

Lestari, dkk., 2012. Manajemen Komunikasi Bencana Merapi 2010 pada saat Tanggap Darurat. Jurnal Ilmu Komunikasi, Volume 10, Nomor 2, hal. 173-197.

Nirwansuah, dkk. 2015. Pengembangan Model Pembelajaran Mitigasi Bencana Gunungapi Slamet BAgi Siswa MI Muhammadiyah Singasari. Prosiding Seminar Nasional Pendidikan Geografi FKIP UMP 2015, ISBN 978-602-74194-0-7, Purwokerto, 13 Juni 2015.

Putra, dkk,. 2014. Pelatihan Mitigasi Bencana Kepada Anak Anak Usia Dini. Jurnal Inovasi dan Kewirausahaan. Vol. 3 No. 2, Mei 2014 Halaman 115-119

Waluyanto, Heru Dwi. 2010. Komik sebagai Media Komunikasi Pembelajaran. Jakarta, (Online), (http://dgi-indonesia.com/komik-sebagaimedia-m), diakses 9 September 2017. 